\title{
READERS nsight
}

\author{
Journal of Economic Info (JEI) \\ ISSN:2313-3376 \\ www.readersinsight.net/jei
}

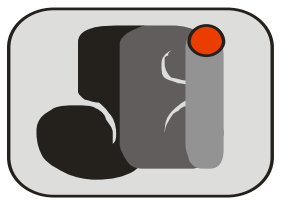

\section{An Investigation of the Level of Compliance with Financial Reporting Standards (FRS 101) by Malaysian SMEs}

\author{
${ }^{1}$ Azhar Abdul Rahman, ${ }^{2}$ Mohd Diah Hamdan
}

${ }^{1}$ Universiti Utara Malaysia

* Corresponding author. azhar258@uum.edu.my

\begin{abstract}
Purpose

This study aims to investigate the association between five firm-specific characteristics and the level of mandatory compliance with Financial Reporting Standards (FRS 101), which is equivalent to International Accounting Standards (IAS) 1 by Malaysian SMEs.

Design/Methodology/Approach

A disclosure index is used to measure the extent of compliance with FRS 101. Each of the 105 sampled firms' annual reports were examined against the index for the financial year ending December 31, 2013.

Findings

The results reveal an overall compliance of 96 per cent. Regression results report that only firm size and profitability have a positive and negative significant association, respectively, with FRS 101 disclosure requirements.

Practical Implications

This study should be particularly relevant to regulatory bodies in Malaysia for strategizing and encouraging compliance with FRS 101 by non-listed firms.

Originality/Value

Additionally, the study contributes to financial reporting literature relating to a developing country, Malaysia. Since SMEs in Malaysia contribute significantly to the economic development in the country, it is interesting to examine how they present their financial statements to interested parties and the degree of their compliance with Financial Reporting Standards as required by the relevant authorities.
\end{abstract}

Keywords: Financial reporting standards, FRS 101, Malaysian SMEs

\section{ARTICLE INFORMATION \\ Received: 10 Dec 2018 \\ Revised: 10 Jan 2019 \\ Accepted: 31 Jan 2019}

DOI: $10.31580 /$ jei.v6i1.496

\section{INTRODUCTION}

At present, many countries around the world are using International Financial Reporting Standards (IFRSs), including Russia, India, Hong Kong, Australia, Malaysia, South Africa, the European Union (EU) and the Gulf Cooperation Council (GCC) countries. It has been reported that since October 2017, 166 countries have been required to adopt IFRSs for companies listed locally (Deloitte Touche Tohmastu, 2017). The motivation for this significant change is the globalization of financial markets, where there is a need to create a consistent, transparent and comparable global approach to financial accounting that will enable investors to compare the performance of corporations regardless of what countries they operate in due to reduction in information asymmetries (Latifah et al. , 2012).

Consequently, the topic of IFRSs as an international accounting standard (IAS) has garnered the interest of many researchers, which has subsequently led to more in-depth studies on this topic. The issue of compliance of IFRS has become more important in both developing and developed countries, with more research concentrating on the latter. Furthermore, moving on to the developing countries, AlShammari et al. (2008) report that non-compliance with IFRS is higher than in developed countries, indicating limited compliance enforcement and oversight by bodies in these countries that supervise financial reporting.

Since the adoption of IFRS in 2005 in an attempt to improve the quality of financial reporting in Malaysia, only a handful of studies address the issue of compliance of IASs and IFRSs in Malaysia. All the studies only examined listed companies in Bursa Malaysia, and none have investigate unlisted companies such SMEs. Rahman and Hamdan (2017), for instance, only focus on listed companies in the ACE market, while Abdullah et al. (2013) and Abdullah et al. (2015) merely focus on listed companies on the main board.

Therefore, due to the infancy of studies regarding this area in Malaysia, this research draws on studies by Rahman and Hamdan (2017), Abdullah et al. (2013), Abdullah et al. (2015), Alfaraih, 2009; Al-Mutawa, 2010; Juhmani, 2012; Demir and Bahadir, 2014, to extend on previous research available in the developing countries and address the issue of non-compliance. Therefore, to aid standard setters and regulatory bodies in Malaysia in instituting strategies and to encourage compliance with IFRSs by the listed firms, this research aims to examine the extent to which Malaysian SMEs comply with the IFRSs, in particular, to determine the level of FRS 101 compliance and the firm-specific characteristics that influence these levels, as no prior research has examined FRS 101 on its own merit. It is a very important 
standard discussing the Presentation of Financial Statements which are used by both domestic and foreign investors. Malaysia is a financial hub, and it is interesting to examine how financial statements are presented to investors and the degree of their compliance with IFRSs since its adoption in 2006. Although the findings of this study are specific to Malaysia, the results of this research are relevant to other countries in the region with similar socio-economic environments.

The study, therefore, examines the association between five firmspecific characteristics and the extent of mandatory compliance with FRS 101 by Malaysian SMEs registered under the CCM. These characteristics include: firm size, leverage, firm age, profitability, and liquidity. The main difference between this study and Rahman and Hamdan's study in 2017 is that, this study only include firm characteristics while the latter includes corporate governance parameters (board characteristics and ownership structure) and other firm characteristics. Another important difference is that, while Rahman and Hamdan's (2017) study consider listed companies, this study focuses exclusively on compliance level of unlisted SMEs, which has not been examined before in the Malaysian context. Therefore, this paper tries to bridge the gap in the extant literature.

The research objectives can be summarized as research questions of the type:

$R Q 1$. What is the extent to which Malaysian SMEs comply with FRS 101?

$R Q 2$. What characteristics are associated with and explain the level of the level of compliance with FRS 101 required disclosures?

It is not presumed that definitive answers to the questions raised exist. The "correct" answers will vary across companies, industries and sectors. Having said that, based on the findings of the research, the researcher proposed recommendations that might aid standard setters and regulatory bodies in Malaysia to formulate strategies to encourage compliance with IFRSs by the SMEs. Furthermore, such research is not only significant for investors, standard setters and other users of financial statements but it also raises concerns regarding the effectiveness of the regulatory bodies, mainly the CCM and MIA and MASB, that oversee the compliance with IFRS in Malaysia.

In addition, managers may realize the importance of information disclosure and learn the determinants of better disclosure practices. This will result in better provision of information to stakeholders. Thus, investors will make healthier and economically sound decisions regarding their investing activities. According to the MASB website, the main purpose of FRS 101 is to establish the basis of the Presentation of Financial Statements, therefore ensuring comparability both with the firms' own financial statements regarding prior periods and with the financial statements of other firms. Standards for recognizing, measuring and disclosing specific transactions are addressed in other standards and interpretations. The standard concerns all generalpurpose financial statements that are prepared and presented in accordance with MFRSs, which are almost identical with IFRSs. General-purpose financial statements are those expected to serve users who are not in a position to require financial reports designed to meet their specific information needs.

This study is organized as follows, where Section 2 reviews the literature that has been published in the area and the development of the hypotheses introduced in the introduction chapter. Section 3 describes the research methods used for data collection and Section 4 reports the results. Finally, the Section 5 draws conclusions, states implications and suggestions for future research. It also covers the limitations faced by the researcher.

\section{LITERATURE REVIEW}

\section{The Corporate Financial Reporting Environment in Malaysia}

Malaysia, a member of the ASEAN countries, has an estimated population of 32 million as of 2018 and land area of $328,550 \mathrm{~km}^{2}$ (Coleman, 2014). Based on the International Monetary Fund (IMF), the gross domestic product (GDP) per capita is US\$9,808, with GDP of US\$ 314.4 bn [International Monetary Fund (IMF), 2018]. Moreover, according to the International Futures Malaysia's profile, the average life expectancy is 75.78 years and the literacy rate is 95.19 per cent (IFs, Version 7.08). The people of Malaysia have a relatively high rate of literacy with an unemployment rate of only 3.4 per cent (DOSM, 2018).

The development of accounting standards in Malaysia only began in the late 1970s and most of the accounting standards were adoption of the International Accounting Standards (IAS) (Tan, 2000). It follow IFRSs issued by the IASB as they are considered as benchmarks for comparison, Additionally, Malaysia is a small country and there may be a lack of expertise to develop standards. So, it will be too expensive to develop local standards. The first financial reporting regulation in Malaysia was introduced under the Companies Ordinance (amendments) of 1940 (Tan, 2000). Further Ordinances followed in 1946 and 1956. The Ordinances played a major role in regulating financial reporting during the period until the Malaysian Companies Act (based on the Victorian Act 1961) was enacted in 1965. Prior to the establishment of the Act, there had been calls for greater regulation in financial reporting. Babiak (1966) for instance, noted the weaknesses and the absence of uniform accounting standards, areas in which improvements were needed. A major turning point in the history of financial reporting in Malaysia started in the mid-1990s when several major events that resulted in significant impact upon financial reporting regulations have taken place. For example, the enforcement of the Financial Reporting Act 1997 took place on 6 March 1997 that saw the establishment of the MASB and the Financial Reporting Foundation (FRF).

Malaysia's the reporting environment also shares features with code law countries: the importance of banks as capital providers (Ball et al., 2003;Suto, 2003; Zhuang, Edwards, Webb, \& Capulong, 2000), high ownership concentration, insider governance, weak investor protection and enforcement, and strong government intervention in the economy (Hasnan et al., 2013; Suto, 2003; Tam \&Tan, 2007; Zhuang et al., 2000). Public listed companies are required to comply with accounting standards, the Companies Act, the Securities Commission guidelines, Bursa listing requirement and the Income Tax Act (Tan, 2000). Accounting standards are issued by the Malaysian Accounting Standards Board (MASB), whose activities and operations are overseen by the Financial Reporting Foundation (FRF). Both the FRF and the MASB were established in 1997 under the Financial Reporting Act 1997. MASB also plays an important role in promoting high compliance of financial reporting by companies by adopting IFRSs issued by the IASB. Convergence with IFRS was implemented in several phases. In January 2005, the MASB standards were renamed Financial Reporting Standards (FRS) and their numbering changed to correspond to that of IFRS (Malaysian Institute of Accountants (MIA), 2005). The FRSs then comprised 21 new and 17 revised standards, which became effective on 1 January 2006. Their content largely matched that of the corresponding IFRS; for 12 standards, it was identical. This caused changes in recognition, measurement and disclosures, and required effort at the implementation stage (Deloitte, 2006). Malaysia aimed for full convergence of its remaining standards with IFRS by 1 January 2012. The Malaysian FRSs (MFRS) since issued by the MASB are identical to IFRS in all respects other than nomenclature. Two bodies monitor financial reporting quality: the Financial Reporting and Corporate Surveillance Department (a department of the Securities Commission (SC)) and the Financial Statement Review Committee of MIA. However, research suggests that enforcement is weak (e.g. Ball et al., 2003; Liew, 2007; Tam \& Tan, 2007; Zhuang et al., 2000). The Surveillance Department's effect is limited: between 2015 and August 2018 out of 65 cases that were investigated only 40 cases were completed. On the other hand, the MIA's Review Committee only reviews a small number of cases (approximately 22-30 per year). In spite of this, a significant number of cases of non-compliance with accounting requirements are identified. This also indicates that non-compliance is a problem.

In summary, in spite of the common law legal framework and British colonial influence on accounting, the Malaysian environment leads us to expect low compliance with disclosure requirements. This, and the scarcity of research on financial reporting by SMEs, motivate our exploration of the extent of mandatory disclosure, and of the factors 
that might influence such disclosure. The next section describe the background of Malaysian SMEs while the theoretical underpinnings of these explorations are presented in section 2.3.

\section{Malaysian SMEs}

Since 2005, the National SME Development Council (NSDC) provided a common definition for Malaysian SMEs as follows:

- Manufacturing (including agro-based) and Manufacturing-related Services: Sales turnover of less than RM25 million OR full-time employees of less than 150

- Primary Agriculture and Services (including ICT): Sales turnover of less than RM5 million OR full-time employees of less than 50 However, from October 2013, a new definition was formulated as follows:

- Manufacturing: Sales turnover not exceeding RM50 million OR full-time employees not exceeding 200 workers

- Services and other sectors: Sales turnover not exceeding RM20 million OR full-time employees not exceeding 75 workers

In a developing country like Malaysia, small and medium enterprises (SMEs) in the manufacturing sector contribute significantly to the economic growth. Approximately $99.2 \%$ of total business establishments in Malaysia are SMEs. These SMEs contribute 32\% of the nation's GDP and 19\% of the total export value (SME Corp. Malaysia, 2014). According to the Department of Statistics Malaysia (2012), SMEs' contribution to GDP increased from $29.4 \%$ in 2005 to $33.1 \%$ in 2013. Besides that, SMEs generate $59 \%$ of jobs in Malaysia (SME Corp. Malaysia, 2017). Currently, there are 37,861 out of 39,669 manufacturing companies in Malaysia are SMEs (Department of Statistics, 2011), which means, approximately $95.4 \%$ of manufacturers are SMEs. From 2005 to 2013, the SME manufacturing sector was the second largest contributor to Malaysia's GDP, after the services sector. However, contribution of SME in the manufacturing sector to the country's GDP had declined from $8.1 \%$ in 2005 to $7.4 \%$ in 2009 , then improved after 2010 increasing to $7.7 \%$, and climbed to $7.9 \%$ in 2011 . Nevertheless, the SMEs manufacturing sector's contribution toward the GDP was lower as compared to the GDP growth achieved in year 2005 to 2007. If the new Masterplan (2012-2020) is successfully implemented, it will contribute $41 \%$ of the GDP, $62 \%$ of employment and $25 \%$ of the total export value to the economy by 2020 .

Most of the Malaysian SMEs are family owned. Particularly, 72\% family owned firms exists in Malaysia and this is the situation in many developing countries. Similarly, 60\% SMEs are family concentrated and they do not practice corporate governance well (Himmelberg et al, 2004). Mostly the families have control over management of the firms (Claessens et al, 1999; Claessens et al, 2002; Khatri et al, 2002). According to Ibrahim \& Samad (2011), family concentration in Malaysian firms increased from $57.7 \%$ (2011) to $67.2 \%$ (2012) and the cut off level for voting has increased from $10 \%$ to $20 \%$. They further expressed that, the Malaysian SMEs structure reflects concentrated ownership and high agency cost due to fraudulent behavior of the majority shareholders.

\section{Theoretical Framework}

According to Healy and Palepu (2001), corporate disclosure serves an important role for the effectiveness and efficiency of a capital market. They argue that companies provide disclosure using financial reports which are regulated, including the financial statements, footnotes, management discussion and analysis and other regulatory filings. Besides, some companies also provide voluntary communication, such as management forecasts, analysts' presentations and conference calls, press releases, internet sites and other corporate reports. Lastly, there are disclosures regarding firms by information intermediaries, such as industry experts, financial analysts and the financial press.

The IASB believes that the purpose of financial statements is to deliver information with respect to the financial performance, position and changes of financial positions of an organization that is useful to a wide-ranging number of users in making informed economic decisions
(International Accounting Standards Board (IASB), 2001). However, Cairns (1997) states that the IASB and the International Federation of Accountants (IFAC) had criticized the auditors who claim that financial statements comply fully with IASs while, in fact, the accounting notes and policies imply otherwise. Street et al. , 1999; Street and Gray, 2001; Glaum and Street, 2003, and Al-Shammari et al. , 2008 found significant levels of IASs non-compliance, and that the extent of compliance by firms that claim to comply with IAS is varied. This supports the criticism made by both the IASB and the IFAC. More importantly, Al-Shammari's (2008) study shows a significant variation in compliance levels among GCC countries and firms. The overall compliance level for all GCC firms during the period under study, 1996 to 2002 , was 75 per cent, and there was a rise in compliance over time from 68 per cent in 1996 to 82 per cent in 2002. Another recent study conducted by Aljifri et al. (2014) revealed that the overall mean value of disclosure in the UAE is 57 per cent, reflecting a low-to-moderate level of disclosure. This suggests that non-compliance is widespread and is possibly higher than that in developed countries.

In addition to determining the degree of compliance with IFRS, previous researches have investigated the association of several firmspecific characteristics with the disclosure level of annual reports of firms. These characteristics include firm size, firm age, leverage, listing status, profitability, auditor type, industry type internationality and liquidity.

Most of the relevant and related studies cite and use Jensen and Meckling's (1976) agency theory that provided the clear foundations of the agency relationships, as a framework for their research and hypotheses development. Additionally, prior literature utilizes the agency theory to justify managers' incentives for disclosure. Basically, the theory concerns the issues that result from shareholders (principals) depending on managers (agents) to provide services on their behalf, due to the separation of both control and ownership. That is if parties act in self-interest, the conflict of interest between them increases, thus there is an increase in agency costs (Alfaraih, 2009). Accordingly, to lower such costs, managers are motivated to disclose additional accounting information as a means of improving transparency.

Another theory, put forth by Alfaraih (2009), that justifies managers' disclosure incentives is the signaling theory, which is a market-based theory underlying the agency theory. The signaling theory argues companies disclose more comprehensive information to the market when their performance is better, than when they hold bad news to avoid their shares from being undervalued. It assumes that managers want to signal that they are pursuing shareholders' wealth maximization and that they are efficient. This assumes that there are ways managers can transmit such signals and that there are investors who receive these signals (Tsalavoutas, 2009).

\section{Hypotheses Development}

Prior studies suggest that corporate compliance with mandatory disclosure is influenced by certain company-specific characteristics (e.g. Rahman and Hamdan, 2017; Abdullah et al., 2015; Wallace et al., 1994; Owusu-Ansah, 1998, 2000; McNalley et al., 1982; Chow and Wong-Boren, 1987; Cooke 1989, 1991; Craswell and Taylor, 1992; Meek et al., 1995; Wallace and Naser, 1995; Inchausti, 1997; Dumontier and Raffournier, 1998; Street and Bryant, 2000; Street and Gray, 2001; Glaum and Street, 2003; Ali et al., 2004; Akhtaruddin, 2005; Alsaeed, 2006; Al-Shammari et al. (2008); Hodgdon et al., 2009; Hossain and Hammami, 2009; Al-Mutawaa and Hewaidy, 2010; AlShammari, 2011; Juhmani, 2012; Glaum et al., 2013). The characteristics considered include size, listing status, leverage, profitability, dispersion of stock ownership, industry, type of auditor, and country of origin. Overall, these studies indicate that size and listing status are significantly associated with the level of disclosure. Findings regarding the relationship between level of disclosure and other corporate variables have been mixed (see Street and Gray [2001] for a review).

In this study, the influences of five firm characteristics, namely, firm size, age, liquidity, profitability and leverage on mandatory disclosure compliance levels of Malaysian SMEs are investigated. In 
this section, several relational conjectures, based on economic theories, prior results, and a priori reasoning, between each corporate-specific characteristic and compliance with mandatory disclosure are made.

Rahman and Hamdan (2017) investigate the association between four corporate governance characteristics and two firm-specific characteristics and the level of mandatory compliance with FRS 101 (similar to IAS 1) by 105 Malaysian companies listed on the ACE market in 2009. They find an overall disclosure compliance of $92.5 \%$. Further, only firm size is positively associated with the degree of compliance. The other variables consisting of board independence, audit committee independence, CEO duality, the extent of outside blockholders' ownership, and leverage do not show any significant relationship with the degree of compliance.

Abdullah et al. (2015) examine the effect of family control on IFRS mandatory disclosure levels, and the valuation implications of these disclosure levels, for 221 Malaysian companies for the year 2008. They find that family control is related negatively to disclosure and that compliance levels are not value relevant. One of the Malaysian accounting standards examined was FRS101, which is similar to the current study. They find that the Malaysian listed companies' overall compliance level with FRS101 was 95 per cent. The findings also reveal that firm size has a negative association with compliance level. They also find that agency theory predictions and theories linking common law legal systems to high quality financial reporting require refining in certain national contexts.

Abdullah et al. (2013) investigates the mandatory disclosure practices evident in the annual reports of 225 Malaysian public listed companies. They find that none of the examined companies fully met the mandatory disclosure requirements even though the companies' management had declared that the financial statements were prepared in accordance with the approved accounting standards. They also observed an inappropriate usage of 'boilerplate' practice in the preparation of financial statements, whereby the companies disclosed certain information that was irrelevant to their circumstances. As for compliance level with FRS101, they find that the overall disclosure score was 95.5 per cent, indicating a high level of compliance.

In his paper, Juhmani (2012) examined the compliance level of 27 IFRSs by Bahraini listed companies in their corporate annual reports for the year ending 2010, using a general disclosure index. He finds an overall compliance of 80.7 per cent. Moreover, the results reveal that large firms disclose more information than small firms. Moreover, companies audited by the Big 4 comply with mandatory IFRSs disclosure requirements more than the companies audited by small audit firms. On the contrary, the other three independent variables such as age, profitability and leverage were found to be insignificant to the compliance level.

An earlier study by Al-Mutawa (2010) examined the disclosures of financial statements of 48 non-financial Kuwaiti firms for the financial year ending in 2006. The findings reveal that only firm size and industry type have a positive association with IAS disclosures requirements. Additionally, all the remaining independent variables are either negatively (leverage) associated with compliance level or positively (other variables), but statistically insignificant. While Al Mutawa (2010) focused on non-financial companies, Al-Shammari (2011) investigated the extent of disclosure compliance with IFRSs by 168 firms listed on the Kuwait Stock Exchange for the year ending 2008. He found that the extent of compliance is negatively related to liquidity and positively related to firm size, age, auditor and internationality, with an overall compliance equalling 82 per cent.

Similarly, Galani et al. (2011) and Aljifri et al. (2014) report that size is the most influential firm characteristic in explaining mandatory disclosure practices. The regression analysis revealed a significant and positive relation between disclosure level and firm size. On the other hand, it is noticed that profitability and company age have no significant association with mandatory disclosure level. These findings are supportive of Alfaraih's (2009) findings that that firm size is statistically significant to the degree of compliance. However, there are mixed findings on the association between the extent of compliance and other firm characteristics.
Al-Shammari et al. (2008) argue that one reason for this result could be that larger firms own more resources to spend on compliance and are less likely to be affected by disclosure of information than smaller companies. Another possible reason is that larger companies may be older, with more conventional reporting systems, meaning that compliance is less costly for them. Moreover, larger companies are expected to be more international, that is, having more foreign investors, foreign sales or foreign stock exchange listings. Conversely, Glaum and Street's (2003) study failed to find any association between corporate compliance of IFRS and firm size. Thus, notwithstanding on the basis of the literature, we hypothesize that:

H1. There is a positive association between firm size and FRS 101 disclosure.

Following a similar methodology, Demir and Bahadir (2014) find that the disclosure compliance by listed Turkish companies varies by audit firm size and leverage, while the remaining characteristics including company age and size are insignificant. Leverage, however, was negatively related to the extent of disclosure compliance. However, in contrast to their finding of leverage, Alsaeed (2006) claims that companies with higher amounts of debt in their capital structure are more likely to incur higher agency costs. Therefore, managers are motivated to lower these agency costs by disclosing more accounting information to satisfy the needs of the creditors. On the other hand, Juhmani (2012) found that leverage was insignificant to compliance levels by firms listed in Bahrain Bourse. To examine the relation between leverage and the level of compliance with FRS-101 among SMEs in Malaysia, it is predicted that:

H2. There is a positive association between leverage and FRS 101 disclosure.

With regards to non-financial companies in India, Bhayani (2012) found that firms with large size of assets, higher profitability, higher leverage, listing in foreign stock exchanges, lower holding of promoters' share and audited by the Big 4 are inclined to be more transparent and therefore disclose more information. However, the age of a company and residential status do not significantly influence the extent of corporate disclosure. In terms of firm age, Bhayani's (2012) result is in line with that of Alsaeed (2006); Juhmani (2012) and Demir and Bahadir (2014). While, Al-Shammari (2011) reports a positive association between the mandatory IFRS disclosure and firm age, Glaum and Street (2003) argue that younger firms tend to have poor accounting systems, giving rise to lower-quality accounting and disclosures. Generally, findings regarding the association between firm age and degree of compliance vary. It is, hence, hypothesized that:

H3. There is a positive association between firm age and FRS 101 disclosure.

The influence of profitability on the extent of IFRS compliance is probably linked to the signaling theory, where managers are willing to share their success to prospective investors and shareholders to raise capital. Nevertheless, Glaum and Street (2003); Alsaeed (2006); AlShammari et al. (2008) and Juhmani (2012) found that profitability is insignificantly related to the extent of compliance with IFRSs mandatory disclosures. On the contrary, Abdullah et al. (2015) found a positive association between the two variables in the Malaysian context. Therefore, to test the association of profitability with the level of FRS-101 compliance from a Malaysian perspective, it is hypothesized that:

H4. There is a positive association between profitability and FRS 101 disclosure.

Al-Mutawa (2010) defined liquidity as the capacity of a firm to pay back its commitments and obligations in the short run. Empirical evidence on the association between liquidity and level of disclosures remains inconclusive. For instance, Al-Mutawa (2010) found a positive, yet insignificant, association between liquidity and level of disclosure whereas Abdullah et al. (2015) found a positive association between the two variables. On the other hand, Al-Shammari (2011) reported a negative association between the two. To test this association for unlisted SMEs in Malaysia, it is hypothesized that:

H5. There is a positive association between liquidity and FRS 101 disclosure. 
To summarize, this study examines the association between five firm-specific characteristics and compliance with mandatory disclosures in Malaysia, expanding on Abdul Rahman and Hamdan's (2017) study to find whether compliance levels are different for unlisted SMEs compared to listed firms, thus providing important feedback to accounting regulators in Malaysia. The agency and signaling theories derived from the literature are regarded as particularly relevant for the purposes of this research study.

\section{RESEARCH METHODOLOGY}

\section{Sample Selection}

To address the research questions, this study adopts a quantitative research design to evaluate the level of SMEs' mandatory compliance with FRS-101 in Malaysia. Their names were requested from the Companies Commission of Malaysia (CCM), which consist of firms that have submitted their FS to the CCM. These companies fall into two major sectors: manufacturing and services. To ensure that no bias was introduced into the analysis by including companies which, because of their activities, were unable to disclose some of the items in the disclosure index, only those non-financial companies with a primary interest in manufacturing activities were included. The population consist of 300 manufacturing companies (provided by the CCM) and from this, 135 companies were selected using random sampling. However, 30 companies are eliminated because of incomplete data. Therefore, the final sample consists of 105 manufacturing companies registered with the CCM.

The data for measuring the dependent and independent variables investigated in this study were collected manually from the sampled companies' annual report obtained from CCM. The reports of 2013 were selected because they were quite recent at the time the study was undertaken and they were easier to obtain.

\section{Development of Disclosure Compliance Index (The Dependent Variable)}

The unweighted disclosure index, also known as the dichotomous disclosure index, is used in this research, as it is the most common method used for determining the firms' compliance with mandatory disclosure requirements. This approach provides equal weighting to the items required to be disclosed by the standards (Demir and Bahadir, 2014). Additionally, it is claimed that when a large number of disclosure items are examined, weighted and unweighted disclosure indices will provide similar findings (Marston and Shrives, 1996 as cited by Al-Mutawa, 2010).

Based on that, a disclosure index was developed with reference to IFRSs issued by the IASB, indices used in prior research (Alfaraih, 2009) and the disclosure and presentation checklist published by Deloitte Touche Tohmastu (2014). For scoring, a score of "1" is assigned if compliance with IFRSs provision under the FRS 101 is disclosed in the annual report for the year under investigation, and "0" for non-compliance. Appendix 1 shows the disclosure index. The disclosure index for each company is calculated by dividing the number of items reported and disclosed in the firm's annual report by the required/relevant items. Consistent with prior compliance research, Street and Gray (2001); Al-Shammari et al. (2008), and Demir and Bahadir (2014) the index that will be used is defined as:

$$
\begin{aligned}
& \mathrm{m} \\
& \mathrm{TD}=\sum_{i=1} \mathrm{~d}_{i} \\
& \text { where } \mathrm{d}=1 \text { if the item } \mathrm{d}_{i} \text { is disclosed, } \\
& \mathrm{d}=0 \text { if the item } \mathrm{d}_{i} \text { is not disclosed, and } \\
& m \leq n \text { (discussed below) } \\
& \mathrm{TD}=\text { total disclosure score }
\end{aligned}
$$

It should be noted that scoring is not a straightforward task since there were cases where companies did not mention an item of disclosure because the item is not relevant to them. If that was the case, a non-disclosure was not considered as a penalty. In contrast, if a relevant item was not disclosed, a score ' 0 ' was assigned, which thus constituted a penalty. In deciding whether an item was of relevance to a company, several procedures used in prior literature were applied. First, following Cooke (1989), each annual report was thoroughly read to ascertain whether an undisclosed information item was, in fact, irrelevant to a company. Second, as in Owusu-Ansah (1998, 2000), the comparative figures for each information item disclosed in one year's annual report; say 2009, was crosschecked against the preceding (2008), and succeeding (2010) annual reports. Third, by deductive reasoning, relevance of some information items to every company was easily established. For example, when a company has fixed assets, its depreciation policy is expected to be disclosed.

An index was subsequently developed to measure the relative level of disclosure by a company. The index is a ratio of the actual scores obtained by a company to the maximum score possible. Since companies are not penalised for not disclosing irrelevant items, the maximum score $(\mathrm{M})$ a company could earn varies:

$$
\mathrm{M}=\sum_{i=1}^{\sum} \mathrm{d}_{i}
$$

where $d=$ expected item of disclosure, and

$\mathrm{n}=$ the number of items which the company is expected to disclose.

The total disclosure index (TDI) for each company then becomes TD $\square$ M. The index would thus lie between 0 and 1 . A score of 1 indicates that a company disclosed all the relevant items as required by the standards and a score of 0 means that a company did not disclose any of the relevant items.

\section{The Independent Variables}

As derived from the literature review, five firm characteristics were

\begin{tabular}{|c|c|c|}
\hline Variable & Proxy & $\begin{array}{l}\text { Expected } \\
\text { sign }\end{array}$ \\
\hline Company size & Total assets & + \\
\hline Profitability & $\begin{array}{l}\text { Return on assets }(\mathrm{ROA})=\text { Earnings } \\
\text { before interest and tax/Total assets }\end{array}$ & + \\
\hline Leverage & Total debt to total assets ratio & + \\
\hline Company age & $\begin{array}{l}\text { Date of financial statements less date of } \\
\text { establishment }\end{array}$ & + \\
\hline Liquidity & Current ratio of the firms & + \\
\hline
\end{tabular}
examined for their association with the level of disclosure compliance to find whether the extent of mandatory compliance with FRS 101 was affected by firm characteristics. The annual reports of the listed firms were used to obtain the data. Table 1 illustrates the independent variables of the study and their measurements. It also shows that prior studies used similar measurement methods as follows.

Table 1: Summary of the independent variables

\section{Development of the Model}

To assess the association of each firm characteristic with the extent of compliance with mandatory FRS-101 disclosure requirements, the following multiple linear regression model was incorporated into the data:

$\mathrm{TDI}=\alpha+\beta_{1} \mathrm{SIZE}+\beta_{2} \mathrm{ROA}+\beta_{3} \mathrm{LEV}+\beta_{4} \mathrm{AGE}+\beta_{5} \mathrm{LIQ}+\varepsilon$

Where :

DCI : Disclosure compliance index;

SIZE : Natural log of book value of total assets;

ROA : Return on assets (profitability)

LEV : Total debts divided by total assets;

AGE : Company Age;

LIQ : Liquidity;

$\varepsilon \quad$ : disturbance term.

\section{DATA ANALYSIS AND DISCUSSION}

\section{Descriptive Statistics}


Table 2 reports the descriptive statistics for the dependent and independent variables for the sample firms. Moreover, it reports the normality tests of the variables used in the study. The mean of the extent of disclosure compliance with FRS 101 of the 105 firms was 96 per cent, with a minimum of 88 per cent and a maximum of 100 per cent, showing variations in the extent of disclosure compliance with FRS 101 in Malaysia. Furthermore, the maximum percentage indicates that some firms fulfilled all the requirements of FRS 101.

Table 2 Descriptive statistics

\begin{tabular}{|c|c|c|c|c|}
\hline Variable & Mean & Std. dev. & Minimum & Maximum \\
\hline \multicolumn{5}{|c|}{$\begin{array}{l}\text { Panel A: descriptive statistics for the dependent and independent } \\
\text { variables }\end{array}$} \\
\hline $\mathrm{DCl}$ & 0.96 & .022 & .88 & 1.00 \\
\hline Size (RM) & 7549763.19 & 8168420.22 & 80363 & 39182049 \\
\hline Profitability & 0.07 & 0.23 & -1.60 & 0.49 \\
\hline Leverage & 0.79 & 0.84 & 0.02 & 6.06 \\
\hline Age & 22.34 & 9.69 & 8 & 47 \\
\hline Liquidity & 1.77 & 2.01 & 0.01 & 12.08 \\
\hline
\end{tabular}

Although this study is concerned with investigating the level of compliance with FRS 101 in Malaysia, the level of disclosure at 0.83 is higher than Juhmani's (2012) study that reported a 0.81 level of disclosure with IFRSs. This could be due to the fact that Juhmani takes into account a number of different standards, while this study focuses solely on one standard, i.e. FRS 101. Therefore, we can state that the level of compliance with FRS 101 (Presentation of Financial Statements), which sets out the overall requirements for financial statements, is 0.83 . This indicates the level of comparability both with the firms' own financial statements regarding prior periods and with the financial statements of other firms.

Furthermore, studies that are similar to Juhmani's study report the level of disclosure compliance with IFRSs at 0.81 (Glaum and Street, 2003) in Germany, 0.33 (Alsaeed, 2006) in Saudi Arabia, 0.82 (AlShammari et al. , 2008) in the GCC, 0.73 (Alfaraih, 2009) in Kuwait, 0.70 (Al-Muatwa, 2010) in Kuwait and 0.79 (Demir and Bahadir, 2014) in Turkey. However, Alfaraih (2009) further reports a 0.85 level of disclosure compliance with FRS 101 in Kuwait, which is higher in comparison to the figure reported in this study. On the other hand, AlMutawa (2010) reports a 0.77 level of disclosure compliance with FRS 101 in Kuwait, which is lower than the figure reported in this study. It is interesting to note that both studies, Alfaraih's and Al Mutawa's, use the annual reports for 2006, resulting in different levels of disclosure. This could be due to the use of a different number of disclosure requirements in their checklists.

Additionally, as suggested by the minimum and maximum figures, there is a wide range of variation within the independent variables. The mean of liquidity was 1.77 times, with a minimum of 0.01 times and a maximum 12.08 times, while the mean of size was RM7.5 million, with a minimum of RM80 thousand and a maximum of RM39.2 million. The normality distributions of both liquidity and total assets (size) were skewed. Therefore, natural logarithm was used in the regression analysis to mollify skewness and bring the distribution of the variables nearer to normality. This is consistent with prior studies such as Wallace et al. , 1994; Al-Mutawa, 2010 and Demir and Bahadir, 2014. Moreover, the mean leverage for the firms was 79.01 per cent with a minimum 2 per cent, indicating firms with somewhat high debts, and a maximum of 606 per cent, indicating firms with very high debts. Firm age ranges from 8 to 47 with a mean of 22.34. Profitability ranges from -1.60 times to 0.49 times with a mean of 0.07 times, revealing that 1.60 times the amount of equity of the firm was because of operations. The normality test was conducted, and since all the predictive variables are not normally distributed (except for profitability) they were treated using natural logarithm.

\section{Bivariate Correlation Results}


negative association between profitability and the extent of compliance, which is in contrast to the researcher's prediction that it will has a positive relationship. Therefore $H 4$ is supported as can be seen in Table 4. The results provide evidence that there is a negative association between age and the extent of disclosure compliance with FRS 101. It is contrasting with the prediction made. This could be due to the fact that older companies find it difficult to comply with FRS101 standards due to their use of local and predetermined set of standards, and it takes time to comply with international standards such as IASs and IFRSs as fast as younger companies, which are more flexible. Nonetheless, the results are statistically insignificant and therefore, $H 3$ is not supported as well.

Moreover, while many studies (Glaum and Street, 2003; Alsaeed, 2006; Juhmani, 2012 and Demir and Bahadir, 2014) found no association between profitability and the extent of mandatory disclosure, the results of this study indicate otherwise. However it is not in line with the signaling theory which state that managers are more likely to disclose and present detailed information when profitability is high to signal their ability to maximize shareholders' value and avoid undervaluation (Alfaraih, 2009). It also does not support the argument that to hide the various reasons for declining profitability or losses, firms may disclose and present less information. Moreover, Gallery et al. (2008); Alfaraih (2009) found an association between profitability and level of disclosure. Similarly, this study supports H4, albeit having a negative association between profitability and level of disclosure compliance with FRS-101 in Malaysia. Finally, there is a positive association between leverage and liquidity and the extent of compliance but the relationship is not sigificant. Therefore $H 2$ and $H 5$ are not supported.

\section{CONCLUSION}

\section{Conclusion}

In an attempt to improve the quality of financial reporting in Malaysia and since the introduction of FRSs by MASB in 2006, no attempt has been made to investigate the depth of information disclosure and factors that may influence the information disclosure of unlisted SME firms in Malaysia. Therefore, this research investigates the level of compliance with FRS-101 disclosure requirements by 105 SME firms for the financial year ending December 31, 2013 and reports the underlying firm characteristics influencing the disclosure compliance of Malaysian SMEs with FRS-101. A Disclosure Compliance Index was used to measure the extent of disclosure compliance with FRS-101. Each of the 105 sampled firms' annual reports was examined against the index to identify the sampled companies' compliance. A regression analysis was used to test the association between the level of disclosure and five firm characteristics including, firm size, age, leverage, profitability and liquidity.

The findings indicate that the overall extent of compliance with FRS-101 of Malaysian SMEs is 0.96. This result supports the findings of Abdullah et al. (2015) who also report similar score, but for Malaysian listed companies. However, Alfaraih (2016) reports a 0.70 level of disclosure compliance with IFRSs in Kuwait, while Alrawahi and Sarea (2016) report a 0.83 level of disclosure compliance with IAS1 in Bahrain, which are lower than the figure reported in this study, indicating that regulations in Malaysia is much more improved.

The regression analysis indicates that disclosure compliance of 0.96 varies by firm size and profitability. Firm size is positively related to the extent of compliance with disclosure requirements. This implies that larger firms have a higher level of disclosure compliance with FRS 101 due to higher resources available to them such as human capital and financial capital. However, profitability is negatively related to the level of disclosure compliance, which is in contrast to the signaling theory which states that managers are more likely to disclose and present detailed information when profitability is high to signal their ability to maximize shareholders' value and avoid undervaluation. It may indicate that loss-making firms are making higher disclosure to show that they have nothing to hide but to reveal the true nature of their business operations. However, the remaining firm characteristics such as leverage, age and liquidity are insignificant in describing the level of disclosure compliance with FRS 101.

\section{Implications and Contributions}

Practically, the results of the analysis provided in this research should be particularly relevant to regulatory bodies and standard setters. The study, therefore, recommends the CCM and the SME Corporation Malaysia, the regulatory bodies in Malaysia, to organize regular training programs and provide practical guides for full compliance with IFRSs and IASs. Although the results of this paper are specific to Malaysia, conclusions drawn from this research might be relevant to other countries in the region with similar socio-economic environments.

From a theoretical point of view, this study adds to existing literature on the association of firm characteristics and compliance with FRS-101 by investigating firms listed on Malaysia Bourse. Therefore, it expands on international accounting compliance studies in the Asian region, particularly in Malaysia. The findings of this paper are also expected to benefit researchers and users of annual reports in other parts of the world.

\section{Limitations and Future Research}

Similar to any other research, this study has some limitations. Due to time factors, only five variables were regarded and tested for a sample of 105 SMEs in Malaysia. As a result, annual reports for only one year ending December 31, 2013 were used. Therefore, further research would be needed by considering more than one year's annual reports to explore the progress of company's compliance level with IAS/IFRSs disclosure requirements.

Moreover, this research is based on data from only 105 manufacturing companies in Malaysia which may not be representative of the other SMEs in the service sector. Therefore, the sample of the firms selected was based on the availability of data and has influenced the results. Consequently, the findings of this study offer a starting point for similar research undertaking. Another future research could employ a longitudinal approach to see the pattern of compliance over time.

\section{References:}

Abdullah M, Evans L, Fraser I \& Tsalavoutas I (2015) IFRS Mandatory disclosures in Malaysia: The influence of family control and the value (ir)relevance of compliance levels, Accounting Forum, 39 (4), pp. 328 348 .

Abdullah M, Sulaiman N.A., Sapiei N.S. \& Minhat M. (2013) Some Observations on Mandatory Disclosure Practices of Malaysian Public Listed Companies, Middle-East Journal of Scientific Research 17 (9): 1228-1236.

Alfaraih, M. ( 2009 ), " Compliance with international financial reporting standards (IFRS) and the value relevance of accounting information in emerging stock markets: evidence from Kuwait ", Doctoral dissertation, Queensland University of Technology, Queensland .

Ali, M., Ahmed, K. and Henry, D. ( 2004 ), "Disclosure compliance with national accounting standards by listed companies in South Asia ", Accounting and Business Research, Vol. 34 No. 3, pp. 183 - 199

Aljifri, K., Alzarouni, A., Ng, C. and Tahir, M. ( 2014 ), " The association between firm characteristics and corporate financial disclosures: evidence from UAE companies ", The International Journal of Business and Finance Research, Vol. 8 No. 2

Al-Mutawa, A. ( 2010 ), " Disclosure level and compliance with IFRSs: an empirical investigation of Kuwaiti companies ", International Business \& Economics Research Journal, Vol. 9 No. 5, pp. 33 - 50 .

Alsaeed, K. ( 2006 ), " The association between firm-specific characteristics and disclosure: the case of Saudi Arabia ", Managerial Auditing Journal, Vol. 21 No. 5, pp. 476 - 496.

Al-Shammari, B. ( 2011 ), " Factors influencing the extent of mandatory compliance with international financial reporting standards: the case of Kuwaiti listed companies ", Journal of International Business and Economics, Vol. 11 No. 4 .

Al-Shammari, B., Brown, P. and Tarca, A. ( 2008 ), " An investigation of compliance with international accounting standards by listed companies 
in the Gulf Co-operation Council Member States ", International Journal of Accounting, Vol. 43 No. 4, pp. 425 - 447

Bhayani, S. ( 2012 ), " Association between firm-specific characteristics and corporate disclosure: the case of India ", International Conference on Business, Economics, Management and Behavioral Sciences, Dubai, 7 8 January.

Cairns, D. ( 1997 ), " IFAC: 20 years on ", World Accounting Report, 2 October.

Coleman, D.Y. ( 2014 ), " Malaysia 2014 country review ",Country Watch , pp. $3-248$.

Deloitte Touche Tohmastu (2017), IFRS in Your Pocket, $16^{\text {th }}$ ed., available at: www.iasplus.com/en/publications/global/ifrs-in-your-pocket/ifrs-inyour-pocket-2017 (accessed 10 August 2018 ).

Demir, V. and Bahadir, O. ( 2014 ), " An investigation of compliance with international financial reporting standards by listed companies in Turkey ", Accounting and Management Information Systems, Vol. 13 No. 1, pp $4-34$.

Farrar, D. and Glauber, R. ( 1967 ), " Multicollinearity in regression analysis: a problem revisited ", Review of Economics and Statistics, Vol. 49, pp. 92 $-107$

Galani, D., Alexandridis, A. and Stavropoulos, A. ( 2011 ), " The association between the firm characteristics and corporate mandatory disclosure the case of Greece ", International Journal of Social, Human Science and Engineering, Vol. 5 No. 5, pp. $78-84$

Gallery, G., Cooper, E. and Sweeting, J. ( 2008 ), " Corporate disclosure quality: lessons from Australian companies on the impact of adopting international financial reporting standards ", Australian Accounting Review, Vol. 18 No. 3, pp. 257 - 273.

Glaum, M. and Street, D.L. ( 2003 ), " Compliance with disclosure requirements of Germany's new market: IAS versus US GAAP ", Journal of International Financial Management \& Accounting, Vol. 14 No. 1, pp. $64-100$.

Hassan, O.A.G., Giogioni, G. and Romilly, P. ( 2006 ), " The extent of financial disclosure and its determinates in an emerging capital markets: the case of Egypt ", International Journal Accounting, Auditing and Performance Evaluation, Vol. 3 No. 1, pp. 41 - 67

Healy, P. and Palepu, K. ( 2001 ), " Information asymmetry, corporate disclosure, and the capital markets: a review of the empirical disclosure literature ", Journal of Accounting and Economics, Vol. 31 Nos 1/3, pp. $405-440$.

International Accounting Standards Board ( 2001 ), International Accounting Standards Board: Framework for the Preparation and Presentation of Financial Statements, IASB, London .

International Monetary Fund (2018), " Report for Malaysia ", available at: www.imf.org/en/Publications/CR/Issues/2018/03/07/Malaysia-2018Article-IV-Consultation-Press-Release-Staff-Report-and-Statement-bythe-45677 (accessed 7 August 2018).

Jensen, M.C. and Meckling, W.H. ( 1976 ), " Theory of the firm: managerial behavior, agency costs and ownership structure ", Journal of Financial Economics, Vol. 3 No. 4, pp. 305 - 360

Joshi, P.L. and Al-Mudhahki, J. ( 2013 ), " Empirical study of compliance with international accounting standards (IAS-1) by stock exchange listed companies in Bahrain ", Journal of Financial Management and Analysis, Vol. 14 No. 2, pp. 43 - 54.

Judge, G.G., Griffiths, W.E., Hill, R.C., Lutkepohl, H. and Lee, T. ( 1985 ), The Theory and Practice of Econometrics, 2nd ed., John Wiley and Sons, New York, NY

Juhmani, O.I.H. ( 2012 ), " Factors influencing the extent of corporate compliance with IFRSs.: evidence from companies listed in bahrain stock exchange ", Journal of International Business and Economics, Vol. 12 No. 2 , pp. $67-79$

Latifah, I.N., Asfadillah, C. and Sukmana, R. ( 2012 ), " History and development of IFRS and AAOIFI and their future challenge ", Cambridge Business \& Economics Conference, Cambridge, MA, 27-28 June.

Marston, C.L. and Shrives, P.J. ( 1996 ), " A review of the development and use of explanatory models in financial disclosure studies ", paper presented at the 19th Annual European Accounting Association Congress, Oslo .

Naser, K., Al-Khatib, K. and Karbhari, Y. ( 2002 ), " Empirical evidence on the depth of corporate information disclosure in developing countries: the case of Jordan ", Advances in International Accounting, Vol. 13, pp. 99 - 118, available at: www.iasplus.com/en/standards/ias/ias1 (accessed 10 May 2015 ).

Owusu-Ansah, S. ( 1998 ), " The impact of corporate attributes on the extent of mandatory disclosure and reporting by listed companies in Zimbabwe ", The International Journal of Accounting, Vol. 33 No. 5, pp. 605 - 631 .

Patton, J. and Zelenka, I. ( 1997 ), " An empirical analysis of the determinants of the extent of disclosure in annual reports of joint stock companies in the Czech Republic ", European Accounting Review, Vol. 6 No. 4, pp. $605-626$.
Rahman, A. A. and Hamdan, M. D. (2017), 'The extent of compliance with FRS 101 standard: Malaysian evidence', Journal of Applied Accounting Research, Vol. 18 No.1, pp. $87-115$.

SME Corp Malaysia. (2012b). SME master plan 2012-2020. Retrieved from http://www.

smecorp.gov.my/v4/node/2124.

Street, D.L. and Bryant, S.M. ( 2000 ), " Disclosure level and compliance with IASs: a comparison of compliance with and without US listings and filings ", International Journal of Accounting, Vol. 35 No. 3, pp. 305 332

Street, D.L. and Gray, S.J. ( 2001 ), Observance of International Accounting Standards: Factors Explaining Non-Compliance by Companies Referring to the Use of IAS, ACCA Research Monograph No. 74, London

Street, D.L., Gray, S.J. and Bryant, S.M. ( 1999 ), " Acceptance and observance of international accounting standards: an empirical study of companies claiming to comply with IASs ", International Journal of Accounting, Vol. 34 No. 1, pp. 11 - 48

Tai, B.Y.K., Au-Yueng, P.K., Kwok, M.G.M. and Lau, L.W.G. ( 1990 ), " Noncompliance with disclosure requirements in financial statements: the case of Hong Kong companies ", International Journal of Accounting, Vol. 25 No. 2, pp. 99 - 112 .

The Central Bank of Bahrain Rule Book ( 2013 ), available at: www.cbb.gov.bh/assets/Consultations/Vol\%205_Financing\%20Compa nies_PD_2013.pdf (accessed 10 March 2015 ).

Tower, G., Hancock, P. and Taplin, R. ( 1999 ), " A regional study of listed companies' compliance with international accounting standards ", Accounting Forum, Vol. 3 No. 1, pp. 293 - 305

Tsalavoutas, I. ( 2009 ), " The adoption of IFRS by Greek listed companies: financial statement effects, level of compliance and value relevance ", Doctoral dissertation, The University of Edinburgh, Edinburgh .

Wallace, R.S.O., Naser, K. and Mora, A. ( 1994 ), " The relationship between the comprehensiveness of corporate annual reports and firm characteristics in Spain ", Accounting and Business Research, Vol. 25 No. 97 , pp. 41 - 53 .

Yiadom, E. and Atsunyo, W. ( 2014 ), " Compliance with international financial reporting standards by listed companies in Ghana ," International Journal of Business and Management, Vol. 9 No. 10

\section{Further Reading}

International Futures (2018 ), " Malaysia country profile ", IFs Version 7.31, available www.ifs.du.edu/ifs/frm_CountryProfile.aspx?Country=MY (accessed 7 August, 2018 ).

Department of Statistics, Malaysia (DOSM) available at: //www.dosm.gov.my/v1/

Joshi, P.L., Deshmukh, A. and Deshmukh, H. ( 2013 ), " Company characteristics and compliance with IFRS's practice statement (management commentary) by listed companies in Bahrain ", International Journal of Managerial and Financial Accounting, Vol. 5 No. 4, pp. 350 - 366

Owusu-Ansah, S. and Yeoh, J. ( 2005 ), " The effect of legislation on corporate disclosure practices ", Abacus, Vol. 41, No. 1, pp. 92 - 109.

Sarea, A. and Dalal, Z. ( 2015 ), " The level of compliance with international financial reporting standards (IFRS 7): evidence from Bahrain Bourse ", World Journal of Entrepreneurship, Management and Sustainable Development, Vol. 11 No. 3, pp. 231 - 244.

SME Corp Malaysia. (2016-18). SME annual report.

Soliman. M.M . ( 2013 ), " Firm characteristics and the extent of voluntary disclosure: the case of Egypt ", Research Journal of Finance and Accounting, Vol. 4 No. 17, pp. 71 - 80

Uyar, A., Kilic, M. and Nizametten, B. ( 2014 ), " Association between firm characteristics and corporate voluntary disclosure: evidence from Turkish listed companies ", Intangible Capital, Vol. 9 No. 4, pp. 1080 1112 